\title{
Lean Six Sigma Based Administration Municipal Services versus Current Ones: Measuring the Gap from Civil Servants Perspective
}

\author{
Engelbert Zefaj
}

PhD Candidate, University of New York, Tirana / Albania

\author{
Doi:10.5901/mjss.2017.v8n1p359
}

\begin{abstract}
The study compares the ideal municipal administrative services based on Lean Six Sigma with the current quality of administrative services provided by municipality, from the perspective of civil servants. Municipal civil servants have been interviewed and their responses have been analyzed. 12 Critical Success Factors (CSFs') and 36 sub factors have been used for the realization of the research. Statistical methods: Descriptive, Sample t-test, Independent t-test and One Way Anova have been used for the analysis. This research measures the gap, provides statistics and conclusions of the civil servants estimation differences regarding municipal administrative services, civil servants compliance for the identified gap and offers recommendations for administration service improvement in the future.
\end{abstract}

Keywords: Lean Six Sigma, LSS Critical Success Factors, Local Government Administration

\section{Introduction}

Municipalities generally provide services to citizens starting from the issuance of various certificates and permits, collection of taxes and fees, the realization of payments, allocation of subsidies, request's reviewing and response to citizens' etc. Of all government services, those provided by local government most directly affect the day-to-day lives of individuals (Sikander, 2015). Local governments are continually engaged to bring innovations in administrative services by improving the working environment, by installing modern systems and advanced means of communication and information, by training of civil servants in all levels of local government. Changes that improve processes are needed but before starting changing public management model, it is necessary to assess and measure the quality of current services in the municipality. Performance measurement is seen as a tool for improving public budgeting, promoting a better reporting system and modernizing public management (Greiling, 2005). The condition of the quality of services and the need for change, in this regard better than anyone else can help civil servants themselves who are working in the municipality. They are people who are part of the system of communication and information, they spend all the time communicating with citizens (customers) by using devices that are available, by listening their requests and complaints and experiencing pressures and privileges from their superiors. They know best as anyone else to assess performance in the municipal civil administration and their assessments help best to identify defects in the system. It is preferred that all civil servants that perform a task and produce a service for citizens should be involved in the process to improve administrative services. Lean six sigma management model is a suitable model for improving processes in administration, this is been proven in many municipalities in developed countries. Lean six sigma is the name typically given to process improvement programs that attempt to implement an approach that is more robust than either Lean or Six Sigma individually (Maleyeff, 2014). In this research the difference of services based on lean six sigma and those currently provided in the municipality will be investigated, based on the civil servants estimations.

\section{Literature Review}

Lean Six Sigma is a process improvement philosophy which enables people to do a better job, eliminates waste and reduces cost, ultimately resulting in greater process efficiency and customer satisfaction (Martin, 2010, p. 58). It is based on the concept of combining two improvement programs, Lean Enterprise and Six Sigma. Lean is defined by Womack and Jones (1994) as the systematic removal of waste by all members of the organization from all areas of the values stream (Näslund, 2008, p. 273). The concept of LM can be traced to the Toyota Production System (TPS), a manufacturing philosophy pioneered by the Japanese engineers Taiichi Ohno and Shigeo Shingo (Kee, 2010, p. 12). Six Sigma is both a quality management philosophy and a methodology that focuses on reducing variation, measuring 
defects and improving the quality of products, processes and services (S. Furterer, A. K. Elshennawy, 2005). According to Harry and Schroeder (2000) Six Sigma is a concept that was originated by Motorola Inc. in the USA in about 1985. Lean, Six Sigma, and Lean Six Sigma are all variants of continuous improvement systems which have evolved from focused methodologies (Taylor et. al., 2014). Lean Six Sigma methodology is preferred over Lean or Six Sigma or any other continuous improvement methodology for process improvements across all the sectors in service industry (Sunder, 2013). Lean Six Sigma was originally devised to eliminate waste and improve manufacturing quality to no more than 3.4 defects per million opportunities (P. Guarraia, et. al., 2008, p. 1). Lean Six Sigma has been equally beneficial both for manufacturing or service concerns and Large or small scale organizations (X. Zhu, M. Hassan, 2012). A disciplined process improvement methodology, such as Lean Six Sigma, can benefit any organization, from large corporations to small municipalities (Maleyeff, 2007, p. 32). Lean six sigma concept is already being applied in many municipalities in USA and elsewhere as Fort Wayne, North Ayrshire, City of El Paso, Huston City, City of Tyler, City of Irving, Erie County. Successful implementation of lean six sigma usually is influenced by various factors. Brotherton and Shaw (1996) define CSFs as the 'essential things' that must be achieved by the company to identify which areas will produce the greatest "competitive leverages" (Baghban, 2016, p. 3463). There is some literature that suggests factors like leadership, strategic orientation, teamwork, technical approaches (metrics-systems), and training will probably affect LSS application. Psychogios et al. (2012), says that top management commitment, involvement \& support; quality-driven organizational culture; quality-driven training; teamwork in problem solving; direct link between lean six sigma and customer satisfaction; strategic orientation of LSS; supportive technical systems (Tools, Techniques \& IT); clear selection of LSS projects; prior implementation of other quality improvement programs; supportive performance management system are key factors that drive to successful implementation (A. G. Psychogios, L. K. Tsironis, 2012, p. 412). Today in the era of globalization and great competition one of the most important principles and aim of the large reforms is the principle of improving the quality of public services (E.Vanags, I Vanags, I. Vilka, 2006, p. 13). The local governments that have decided to start this innovation path since the early 1990's have developed a new conception in the way they manage their organizations, from improving the quality of the services provided; executing their processes in a more effective and efficient way, to reduce the costs of the municipal management (money saving); until keeping the principle of legality, without being rigid, and guiding and approximating political decisions to the citizens through process standards in order to keep the current social services as higher as possible (Suárez-Barraza, 2013, p. 209). According to Akhakpe (2013), local government administration allows for clientele participation in decision making and implementation of government programs that affect their lives (Agbodike F.C. et. al., 2014, p. 100). Linderman, Schroeder, Zaheer, and Choo (2003) pointed out that six sigma can be implemented on the processes of producing manufacturing goods, business trade, executive management, and services. Service is about people, whether internal or external to the organization, and the relationships between them (Lisa, 2008).

\section{Hypothesis}

Since lean six sigma can ultimately helping companies and institutions achieve zero defects beside prompt delivery at lower costs and better customer satisfaction (Baghban, 2016, p. 3463), then it can be concluded that an organization that is successfully implementing this managerial concept is also offering ideal services to its customers. If a local municipal administration works with zero defects will satisfy the citizens, civil servants and its leadership. The question is whether the local municipal administration is offering ideal services to its citizens, if not, what is the gap between the LSS-based services and quality of services offered currently? In this paper, the gap between LSS-based services and the quality of services offered currently by a municipality in Kosovo is been explored. Hypotheses to be verified are:

$\mathrm{H} 1$ : Municipality in Kosovo is not providing ideal administrative services to the citizens as would be achieved through lean six sigma based services.

H3: There is compliance between civil servants in their estimations regarding the existing gap between quality of LSS-based services and those currently provided by municipalities.

\section{Methodology}

This research was conducted in a municipality which deals with about 97,000 resident inhabitants. Administration of the civil service in the municipality is administered from 14 departments, plus the mayor's cabinet. In this administration are engaged 220 civil servants divided into three administrative levels: Managerial, professional, technical and administrative level. To 159 civil servants was conducted personal interview by using a structured questionnaire. In the questionnaire were 36 questions, three for each critical factor (12 CSF's). Interview questions are formulated on enabling factor basis 
which are presented to the respondents with ideal content for administrative services based on LSS CFS's where respondents give their estimation score from their perspective using 5 options: Poor, Satisfactory, Good, Very Good and Ideal. Critical factors studied were selected from authors (Sunil Sharma, Anuradha R. Chetiya, 2012, p. 298) and (Ayon Chakraborty, Kay Chuan Tan, 2012, p. 998). The collected data were analyzed by using SPSS statistical models as descriptive analysis, One Sample T-test, Independent T-test and One way ANOVA.

\section{Analysis}

In this section are presented demographic profiles of respondents, gap analysis results which was conducted with the "one sample T-test", gender-based differences which is realized by "Independent sample t-test" and group differences that are realized with "Anova". The demographic profile of the respondents shows that $36.5 \%$ of the respondents who participated in the questionnaire were aged from $18-40,30.2 \%$ were aged from $41-52$ and 33.3\% were aged from 53-64. This suggests that the separation of civil servants at the municipality was stratified into three groups, balanced with average around $30.3 \%$. The total number of respondents was 159 with 3 employed at rank and five groups of working experience, $76(47.8 \%)$ were male and $83(52.2 \%)$ female, 19 chief officer's, 111 officer's, 15 assistant's and 14 other in which nearly $50 \%$ of them have been working in municipality for at least 9 years, $34 \%$ at least 18 years, $3.1 \%$ at least 27 years, $10.7 \%$ at least 36 years and $3.1 \%$ at least 42 years.

\begin{tabular}{|c|c|c|}
\hline Age & Frequency & Percent \\
\hline $18-28$ & 13 & 8.2 \\
\hline $29-40$ & 45 & 28.3 \\
\hline $41-52$ & 48 & 30.2 \\
\hline $53-64$ & 53 & 33.3 \\
\hline Total & 159 & \\
\hline \multicolumn{3}{|l|}{ Gender } \\
\hline Male & 76 & 47.8 \\
\hline Female & 83 & 52.2 \\
\hline Total & 159 & \\
\hline \multicolumn{3}{|l|}{ Position } \\
\hline Chief officer & 19 & 11.9 \\
\hline Officer & 111 & 69.8 \\
\hline Secretary & 1 & 0.6 \\
\hline Assistant & 14 & 8.8 \\
\hline Other & 14 & 8.8 \\
\hline Total & 159 & \\
\hline \multicolumn{3}{|l|}{ Experience } \\
\hline $0-9$ & 78 & 49.1 \\
\hline $10-18$ & 54 & 34 \\
\hline $19-27$ & 5 & 3.1 \\
\hline $28-36$ & 17 & 10.7 \\
\hline $37-42$ & 5 & 3.1 \\
\hline Total & 159 & \\
\hline
\end{tabular}

\begin{tabular}{|c|c|c|c|c|c|c|}
\hline \multirow[b]{3}{*}{$\begin{array}{l}\text { Variable/Critical Success } \\
\text { Factor (CSF) }\end{array}$} & \multirow{2}{*}{\multicolumn{2}{|c|}{$\begin{array}{l}\text { Estimation Score } \\
\text { (P) }\end{array}$}} & \multirow{3}{*}{\begin{tabular}{|c|} 
Maximum \\
Score \\
$(\mathrm{M})$ \\
Mean \\
\end{tabular}} & \multirow{3}{*}{$\begin{array}{c}\text { GAP } \\
\begin{array}{c}\text { Mean } \\
\text { difference) }\end{array} \\
\text { (P-M) }\end{array}$} & \multirow{3}{*}{ t-value } & \multirow{3}{*}{$\begin{array}{l}\text { Sig. (2- } \\
\text { tailed) }\end{array}$} \\
\hline & & & & & & \\
\hline & Mean & SD & & & & \\
\hline MNG. INVOLVEMENT & 4.027 & 0.9315 & 5 & -0.97275 & -13.17 & 0 \\
\hline CULTURE & 3.589 & 0.8562 & 5 & -1.4109 & -20.78 & 0 \\
\hline COMMUNICATION & 3.541 & 0.9084 & 5 & -1.45912 & -20.26 & 0 \\
\hline INFRASTRUCTURE & 3.604 & 1.0092 & 5 & -1.39623 & -17.45 & 0 \\
\hline SKILLS & 3.681 & 0.795 & 5 & -1.31866 & -20.92 & 0 \\
\hline STRATEGY & 3.224 & 0.9462 & 5 & -1.77568 & -23.67 & 0 \\
\hline EXPERTS & 3.086 & 0.9173 & 5 & -1.91405 & -26.31 & 0 \\
\hline VISIBILITY & 3.512 & 0.9306 & 5 & -1.48847 & -20.17 & 0 \\
\hline MOTIVATION & 3.193 & 0.9681 & 5 & -1.80713 & -23.54 & 0 \\
\hline TRAINING & 3.331 & 0.9075 & 5 & -1.66876 & -23.19 & 0 \\
\hline EQUIPMENTS & 3.153 & 1.0061 & 5 & -1.84696 & -23.15 & 0 \\
\hline CITIZEN FOCUS & 3.31 & 0.9752 & 5 & -1.68973 & -21.85 & 0 \\
\hline
\end{tabular}

In the Table 2 is presented GAP analysis to see the differences between the estimates of municipal civil servants regarding the quality of services they provide for the citizens and ideal quality to be achieved through the application of Lean Six Sigma (5.0). One sample t-test was used to see the results of the statistical significance. In the first row of Table 2 are presented data for the CSF Management Involvement, which shows that there is a difference between civil servants estimates and the ideal quality based on lean six sigma application. Average estimates are 4.02, the maximum rate based on application of lean six sigma 5.0 and the difference -0.975 .0 . Through the data issued by one sample $t$-test (t=- 
13,167; sig. $0.000<0.005)$ it can be argued that there is statistically significant difference between the civil servants estimation and the ideal quality based on lean six sigma application. In this table, based on estimations of civil servants of the municipality, the differences between the ideal quality based on lean six sigma (5.0) and quality offered by the municipality are evident throughout all CSF's. This table shows that Management Involvement factor has the highest estimate and the smallest difference in comparison to other factors, and the Experts Engagement factor is estimated less than the others and has the highest difference. For Experts Engagement the average estimates are 3.08 out of 5.0 which ideal score is. The difference is -1.91 where $t$-test is ( $t=-26.312$; sig. $0.000<0.005)$. The table shows that differences exist in all factors (CSF's), in all cases we have differences with statistical significance because in all cases we can see sig. $0.000<0.005$. The differences vary from -0.9 which is the smallest and -1.91 which is the largest one. So, the average estimates by civil servants for all CSF's are less than 5.0 .

\begin{tabular}{|c|c|c|c|c|c|c|}
\hline Factor & Gjinia & $\mathbf{N}$ & Mean & t- value & df & $\begin{array}{l}\text { Sig. (2- } \\
\text { tailed) }\end{array}$ \\
\hline \multirow{2}{*}{ MNG. INVOLNMENT } & Male & 76 & 4.0175 & \multirow{2}{*}{-0.125} & \multirow[b]{2}{*}{157} & \multirow{2}{*}{0.809} \\
\hline & Female & 83 & 4.0361 & & & \\
\hline \multirow{2}{*}{ CULTURE } & Male & 76 & 3.6754 & \multirow{2}{*}{1.219} & \multirow{2}{*}{157} & \multirow{2}{*}{0.509} \\
\hline & Female & 83 & 3.51 & & & \\
\hline \multirow{2}{*}{ COMMUNICATION } & Male & 76 & 3.5658 & \multirow{2}{*}{0.33} & \multirow{2}{*}{157} & \multirow{2}{*}{0.054} \\
\hline & Female & 83. & 3.5181 & & & \\
\hline \multirow{2}{*}{ INFRASTRUCTURE } & Male & 76 & 3.5702 & \multirow{2}{*}{-0.401} & \multirow{2}{*}{157} & \multirow{2}{*}{0.185} \\
\hline & Female & 83 & 3.6345 & & & \\
\hline \multirow{2}{*}{ SKILLS } & Male & 76 & 3.6974 & \multirow{2}{*}{0.243} & \multirow{2}{*}{157} & \multirow{2}{*}{0.956} \\
\hline & Female & 83 & 3.6667 & & & \\
\hline \multirow{2}{*}{ STRATEGY } & Male & 76 & 3.2763 & \multirow{2}{*}{0.662} & \multirow{2}{*}{157} & \multirow{2}{*}{0.434} \\
\hline & Female & 83 & 3.1767 & & & \\
\hline \multirow{2}{*}{ EXPERTS } & Male & 76 : & 3.2325 & \multirow{2}{*}{1.944} & \multirow{2}{*}{157} & \multirow{2}{*}{0.526} \\
\hline & Female & 83. & 2.9518 & & & \\
\hline \multirow{2}{*}{ VISIBLITY } & Male & 76 & 3.614 & \multirow{2}{*}{1.332} & \multirow{2}{*}{157} & \multirow{2}{*}{0.441} \\
\hline & Female & 83 & 3.4177 & & & \\
\hline \multirow{2}{*}{ MOTIVATION } & Male & 76 & 3.1974 & 0.056 & 157 & 0.809 \\
\hline & Female & 83 & 3.1888 & & & \\
\hline TRAINRG & Male & 76 & 3.3904 & 0.785 & 157 & 0,509 \\
\hline & Female & 83 & 3.2771 & & & \\
\hline EQUIPMENTS & Male & 76 & 3.2061 & 0.636 & 157 & 0.054 \\
\hline & Female & 83. & 3.1044 & & & \\
\hline CITIZEN FOCUS & Male & 76 & 3.3728 & 0,773 & 157 & 0.185 \\
\hline & Female & 83 & 3.253 & & & \\
\hline
\end{tabular}

Table 3 shows the results of Independent Sample t- test which presents the gender differences in terms of their estimates for the quality of services in the municipality. In the first row of Table 3 data can be learn for Management Involvement factor where the average estimate regarding this factor is with very close difference, where $(M=4.0175$ and $F=4.0361)$. Further we can read the results of $t$-test $(t=-0.125$; sig. $0.809<0.05)$, which means that there is no gender statistically significant difference regarding Management Involvement estimates. Table shows also that by other factors are not noted large differences between the estimates outlined in both genders. The largest pronounced difference is noted by Visibility factor $(\mathrm{M}=\mathrm{F}=3.6140$ and 3.4177$)$ dif. $=0.1963$ while the the smallest difference is noted by Motivation factor where ( $\mathrm{M}$ $=\mathrm{F}=3.1974$ and 3.1888) dif. $=0.0086$. Below, in the tables 4, 5 and 6 measurement analysis on estimation differences based on dimensions like age, work position and experience are presented. Table 4 shows the results of One Way ANOVA and we can see differences on estimation between different age groups. In the first row of the table 4 we can read data for Management Involvement factor and the results are: (age22-age26 $=4.15$, age27-age39 $=3.93$, age 40 age52 $=4.08$ and age53-age $65=4.02$ ), $\mathrm{F}$ value is 0.287 and the significance coefficient is 0.809 . This means that the observed differences have no statistical significance, and that there is more than $80 \%$ chance that these differences happens randomly. According the analysis, it can be concluded that also by other CSFs' there are no statistically significant differences between respondents with different age groups, in terms of civil servants estimations regarding quality services in the municipality. Also based on these data, we can say with much certainty that age has no impact on the assessment of civil servants. Observed data in the tables 4 and 5 shows similar results for assessments based on working position and experience. The differences are also small, no statistical significance difference is observed on civil servants estimation. Example, table 5, "Management Involvement" factor interpretation for working experience says this: (year 0-year $9=4.07 ; \mathrm{y} 10-\mathrm{y} 18=3.88 ; \mathrm{y} 19-\mathrm{y} 27=4.06 ; \mathrm{y} 28-\mathrm{y} 36=4.27$ and $\mathrm{y} 37-\mathrm{y} 42=3.86$ ), $\mathrm{F}$ value $=0.686$ while significance coefficient is: sig. $=0.602$. In the table 6 , "Management Involvement" factor interpretation for working position says following (Chief Officer $=4.03$; Officer $=4.060$; Assistant $=3.64$ and other $=4.02$ ), $\mathrm{F}$ value $=0.679$ and the significance coefficient is sig. 0.61 . Three tables show that differences between groups in the three cases are small, there is no statistically significant difference. This means that municipal civil servants regardless of age, experience or work position have similar opinions about the quality of municipal services. 


\begin{tabular}{|c|c|c|c|c|c|}
\hline Factor & Age & $\mathbf{N}$ & Mean & $\begin{array}{c}\text { F- } \\
\text { Value }\end{array}$ & Sig. \\
\hline \multirow{5}{*}{ 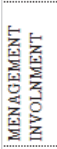 } & $22-26$ & 13 & 4.1538 & \multirow{5}{*}{0.287} & \multirow{5}{*}{0.8} \\
\hline & $27-39$ & 45 & 3.9333 & & \\
\hline & $40-52$ & 48 & 4.0833 & & \\
\hline & $53-65$ & 53 & 4.0252 & & \\
\hline & Total & 159 & 4.0273 & & \\
\hline \multirow{5}{*}{$\begin{array}{l}\text { 剀 } \\
\text { 总 } \\
\text { 它 }\end{array}$} & $22-26$ & 13 & 3.4359 & \multirow{5}{*}{2.042} & \multirow{5}{*}{0.1} \\
\hline & $27-39$ & 45 & 3.4741 & & \\
\hline & $40-52$ & 48 & 3.4792 & & \\
\hline & $53-65$ & 53 & 3.8239 & & \\
\hline & Total & 159 & 3.5891 & & \\
\hline \multirow{5}{*}{ 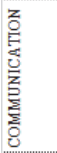 } & $22-26$ & 13 & 3.2564 & \multirow{5}{*}{2.133} & \multirow{5}{*}{0.1} \\
\hline & $27-39$ & 45 & 3.3481 & & \\
\hline & $40-52$ & 48 & 3.5625 & & \\
\hline & $53-65$ & 53 & 3.7547 & & \\
\hline & Total & 159 & 3.5409 & & \\
\hline \multirow{5}{*}{ 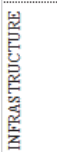 } & $22-26$ & 13 & 3.3077 & \multirow{5}{*}{0.924} & \multirow{5}{*}{0.43} \\
\hline & $27-39$ & 45 & 3.4741 & & \\
\hline & $40-52$ & 48 & 3.6944 & & \\
\hline & $53-65$ & 53 & 3.7044 & & \\
\hline & Total & 159 & 3.6038 & & \\
\hline \multirow{5}{*}{ 苝 } & $22-26$ & 13 & 3.359 & \multirow{5}{*}{1.93} & \multirow{5}{*}{0.13} \\
\hline & $27-39$ & 45 & 3.5333 & & \\
\hline & $40-52$ & 48 & 3.7569 & & \\
\hline & $53-65$ & 53 & 3.8176 & & \\
\hline & Total & 159 & 3.6813 & & \\
\hline \multirow{5}{*}{ 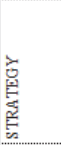 } & $22-26$ & 13 & 3.1538 & & \\
\hline & $27-39$ & 45 & 3.0889 & & \\
\hline & $40-52$ & 48 & 3.1597 & 1.127 & 0.34 \\
\hline & $53-65$ & 53 & 3.4151 & & \\
\hline & Total & 159 & 3.2243 & & \\
\hline & $22-26$ & 13 & 2.7436 & & \\
\hline & $27-39$ & 45 & 2.9556 & & \\
\hline & $40-52$ & 48 & 2.9931 & 2.796 & 0.04 \\
\hline 출 & $53-65$ & 53 & 3.3648 & & \\
\hline 区 & Total & 159 & 3.086 & & \\
\hline & $22-26$ & 13 & 3.0513 & & \\
\hline & $27-39$ & 45 & 3.3333 & & \\
\hline$E$ & $40-52$ & 48 & 3.5972 & 2.527 & 0.06 \\
\hline 를 & $53-65$ & 53 & 3.6981 & & \\
\hline$\overline{5}$ & Total & 159 & 3.5115 & & \\
\hline & $22-26$ & 13 & 3.1026 & & \\
\hline z & $27-39$ & 45 & 3.1185 & & \\
\hline$e_{<}$ & $40-52$ & 48 & 3.125 & 0.606 & 0.61 \\
\hline$\rightleftarrows$ & $53-65$ & 53 & 3.3396 & & \\
\hline$\stackrel{2}{2}$ & Total & 159 & 3.1929 & & \\
\hline & $22-26$ & 13 & 3.4872 & & \\
\hline & $27-39$ & 45 & 3.0296 & & \\
\hline $\mathfrak{z}$ & $40-52$ & 48 & 3.3472 & 2.767 & 0.04 \\
\hline $\bar{z}$ & $53-65$ & 53 & 3.5346 & & \\
\hline$\cong$ & Total & 159 & 3.3312 & & \\
\hline & $22-26$ & 13 & 2.9231 & & \\
\hline 2 & $27-39$ & 45 & 2.9556 & & \\
\hline z & $40-52$ & 48 & 3.1597 & 1.655 & 0.18 \\
\hline 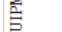 & $53-65$ & 53 & 3.3711 & & \\
\hline $\bar{g}$ & Total & 159 & 3.153 & & \\
\hline & $22-26$ & 13 & 3.0513 & & \\
\hline 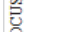 & $27-39$ & 45 & 3.1259 & & \\
\hline$\frac{2}{z}$ & $40-52$ & 48 & 3.4028 & 1.339 & 0.26 \\
\hline 곡 & $53-65$ & 53 & 3.4465 & & \\
\hline 5 & Total & 159 & 3.3103 & & \\
\hline
\end{tabular}

\begin{tabular}{|c|c|c|c|c|c|}
\hline Factor & Position & $\mathbf{N}$ & Mean & $\begin{array}{r}F- \\
\text { Value }\end{array}$ & Sig. \\
\hline \multirow{6}{*}{ 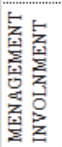 } & Chief officer & 19 & 4.035 & \multirow{6}{*}{0.679} & \multirow{6}{*}{0.607} \\
\hline & Officer & 111 & 4.060 & & \\
\hline & Secretary & 1 & 4.000 & & \\
\hline & Assistant & 14 & 3.643 & & \\
\hline & Other & 14 & 4.143 & & \\
\hline & Total & 159 & 4.027 & & \\
\hline \multirow{6}{*}{ 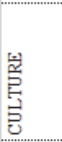 } & Chief officer & 19 & 3.561 & \multirow{6}{*}{1.728} & \multirow{6}{*}{0.147} \\
\hline & Officer & 111 & 3.592 & & \\
\hline & Secretary & 1 & 3.000 & & \\
\hline & Assistant & 14 & 3.214 & & \\
\hline & Other & 14 & 4.024 & & \\
\hline & Total & 159 & 3.589 & & \\
\hline \multirow{6}{*}{ 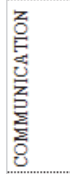 } & Chief officer & 19 & 3.438 & \multirow{6}{*}{1.348} & \multirow{6}{*}{0.255} \\
\hline & Officer & 111 & 3.568 & & \\
\hline & Secretary & 1 & 2.000 & & \\
\hline & Assistant & 14 & 3.309 & & \\
\hline & Other & 14 & 3.809 & & \\
\hline & Total & 159 & 3.541 & & \\
\hline \multirow{6}{*}{ 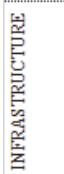 } & Chief officer & 19 & 3.333 & & \\
\hline & Officer & 111 & 3.598 & & \\
\hline & Secretary & 1 & 3.667 & 1412 & 0.232 \\
\hline & Assistant & 14 & 3.476 & 1.412 & 0.252 \\
\hline & Other & 14 & 4.143 & & \\
\hline & Total & 159 & 3.604 & & \\
\hline & Chief officer & 19 & 3.579 & & \\
\hline & Officer & 111 & 3.664 & & \\
\hline & Secretary & 1 & 3.667 & 2556 & 0.041 \\
\hline & Assistant & 14 & 3.381 & 2.556 & 0.041 \\
\hline $\bar{z}$ & Other & 14 & 4.262 & & \\
\hline & Total & 159 & 3.681 & & \\
\hline & Chief officer & 19 & 3.105 & & \\
\hline & Officer & 111 & 3.198 & & \\
\hline 0 & Secretary & 1 & 2.667 & 0,614 & 0.653 \\
\hline 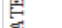 & Assistant & 14 & 3.309 & & \\
\hline ב્ & Other & 14 & 3.548 & & \\
\hline 5 & Total & 159 & 3.224 & & \\
\hline & Chief officer & 19 & 3.211 & & \\
\hline & Officer & 111 & 3.015 & & \\
\hline & Secretary & 1 & 3.000 & 0.586 & 0,673 \\
\hline$\underline{v a}$ & Assistant & 14 & 3.262 & 0.586 & $0.6 / 3$ \\
\hline हn & Other & 14 & 3.309 & & \\
\hline$\underset{2}{2}$ & Total & 159 & 3.086 & & \\
\hline & Chief officer & 19 & 3.526 & & \\
\hline & Officer & 111 & 3.451 & & \\
\hline$E$ & Secretary & 1 & 3.000 & 192 & 0.11 \\
\hline $\overrightarrow{\bar{m}}$ & Assistant & 14 & 3.381 & 1.92 & 0.11 \\
\hline$\stackrel{\Perp}{=}$ & Other & 14 & 4.143 & & \\
\hline 5 & Total & 159 & 3.512 & & \\
\hline & Chief officer & 19 & 3.017 & & \\
\hline 0 & Officer & 111 & 3.168 & & \\
\hline$\sum_{<}$ & Secretary & 1 & 3.333 & 0.854 & 0,493 \\
\hline 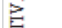 & Assistant & 14 & 3.191 & 0.854 & 0.493 \\
\hline 5 & Other & 14 & 3.619 & & \\
\hline$\Sigma$ & Total & 159 & 3.193 & & \\
\hline & Chief officer & 19 & 3.088 & & \\
\hline & Officer & 111 & 3.303 & & \\
\hline & Secretary & 1 & 2.667 & 3068 & 0.018 \\
\hline$\underline{\underline{z}}$ & Assistant & 14 & 3.191 & & \\
\hline ङ & Other & 14 & 4.071 & & \\
\hline 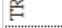 & Total & 159 & 3.331 & & \\
\hline & Chief officer & 19 & 3.123 & & \\
\hline$z$ & Officer & 111 & 3.081 & & \\
\hline 急 & Secretary & 1 & 3.000 & 145 & 0.22 \\
\hline E & Assistant & 14 & 3.167 & & \\
\hline$\overline{8}$ & Other & 14 & 3.762 & & \\
\hline 5 & Total & 159 & 3.153 & & \\
\hline & Chief officer & 19 & 3.105 & & \\
\hline & Officer & 111 & 3.291 & & \\
\hline & Secretary & 1 & 3.333 & 1515 & 0.2 \\
\hline & Assistant & 14 & 3.167 & 1.515 & 0.201 \\
\hline & Other & 14 & 3.881 & & \\
\hline & Total & 159 & 3.310 & & \\
\hline
\end{tabular}




\section{Discussion}

In this part the results that have emerged from the data analysis are discussed. Explanations are given on identified results over the existing gap between LSS standards and current quality of services. Each Critical Success Factor is tackled and explained. It is also discussed on civil servants compliance regarding their estimations. The outcomes of the analysis show that civil servants have provided estimates for most of the critical factors around 3.0 or slightly above. This means that each critical factor is far from the ideal quality which should be the target to be achieved in the future when compared to the value determined of 5.0 based on LSS standards. Data have produced a difference of -1.31 for "skills" which is the best estimated factor and worst estimated factor for "experts" which is -1.91. This means chief offices and officials do not properly follow targeted policies and they don't share them in proper way with other officials, officials are not skilled to identify and report when there is a defect and to make proposals for solving the problem and they are not aware that the their performance has an direct impact on all the chain of administrative service. Regarding the experts factor, there are no sufficient professional human resources and no external experts are engaged for specific projects that improve the quality of administrative services. Critical Success Factor "Management Involvement" makes an exception that has a positive score in this research. This factor was estimated by 4.02 points with only difference of -0.97 far from LSS standards which value in this research was 5.0. This means that the Chief Officers usually when necessary they spend time, even if not at ideal level as LSS standards requires, with employees in the workplace and provides assistance if required, he/she encourages officers to present the problem and solving the problem when it occurs during the process and he/she teach them how to conserve values and principles of the department. Regarding civil servants consistency the data shows that despite gender, age, position or work experience they all share similar estimation about the existing gap between the LSS standards and current services offered by the municipality. Observed results show similar estimations at three levels, meaning that their estimations are self-critical and all the three levels agree that the quality of services is far from the quality of services based on standards of LSS. Civil servants agree that improving quality of services at the levels of LSS, municipality must build contemporary electronic system, civil servants should receive more trainings, should increase confidence in the whole structure of the administration, must improve communication systems and above all municipalities should focus more to the citizens.

\section{Conclusion and Recommendation}

In conclusion, the hypothesis raised in this research are proven completely and can be concluded that the municipalities in the Republic of Kosovo do not provide the ideal quality of services for their citizens as would be the case with the application of lean six sigma standards. To this findings agree civil servants of Kosovo municipalities regardless of age, gender, place of work or experience. The quality of administrative services is an average of 3.5 from 5 points which is ideal level. Since the Republic of Kosovo is a new country, which is only 8 years as an independent country, it can be concluded that the level of administrative services is not disappointing because they are above average of 3.0. Still remains to be worked and improved in municipal service administration in order to satisfy needs of citizens. Since Lean aims to optimize costs, quality, and customer service constantly (N. Bhatia, J. Drew, 2007), municipalities such as is the case with Kosovo, as an emerging country, should be determined as soon as possible to start applying this concept. It is recommended that municipalities begin with application of LSS in selected departments, to plan investment of financial means, expert's engagement, training for most capable civil servants so that in the future they can be leaders of the continuous improvement of administrative services in all municipality. Municipalities need to start using lean six sigma mechanisms and tools in order to identify defects in processes, to understand reasons why their work is not efficient enough.

\section{References}

A. G. Psychogios, L. K. Tsironis. (2012). Towards an integrated framework for Lean Six Sigma application: Lessons from the airline industry. Total Quality Management, 397 - 415.

Agbodike F.C. et. al. (2014). Local Government Administration and the Challenges of Sustainable Development in Nigeria. Review of Public Administration and Management, 95-105.

Ayon Chakraborty, Kay Chuan Tan. (2012). Case study analysis of Six Sigma implementation in service organisations. Business Process Management Journal, 992-1019.

Baghban, G. (2016). A Hybrid Approach to Analyzing the Interrelationship of Critical Success Factors of Lean Six Sigma in Industry. International Business Management, 3461-3471.

E.Vanags, I Vanags, I. Vilka. (2006). The Main Trends and Principles of Public Administration Development throughout the World and in 
Latvia. Viesoji Politika Ir Administravimas, 7 - 16.

Greiling, D. (2005). Performance measurement in the public sector: the German experience. International Journal of Productivity and Performance Management, 551 - 567.

Kee, T. L. (2010). Critical Success Factors (CSFs) for Lean Six Sigma (LSS) Implementation and Its Impact on the Performance of Electronic Manufacturing Services (EMS) Industries. Universiti Sains Malaysia, 1 - 169.

Lisa, M. (2008). Quality Management in the public sector; applying lean concepts to customer service in a consolidated government office. Public Administration Quarterly Summer, 282-301.

Maleyeff, J. (2007). Improving Service Delivery in Government with Lean Six Sigma. IBM Cente The Business of Government, 04 - 42.

Maleyeff, J. (2014). Sustaining Public Sector Lean Six Sigma: Perspectives from North America. Management and Organizational Studies, 92-99.

Martin, J. (2010). Increasing Public Sector Productivity Could Lean Six Sigma heip improve services? Accountancy Ireland, 58-59.

N. Bhatia, J. Drew. (2007). Applying lean production to the public sector. The McKinsey Quarterly: The Online Journal of McKinsey \& Co, $1-5$.

Näslund, D. (2008). Lean, six sigma and lean sigma: fads or real process improvement methods. Business Process Management Journal, 269 - 287.

P. Guarraia, et. al. (2008). Lean Six Sigma for the services industry. Los Angeles, Chicago, Dusseldorf: Bain \& Company.

S. Furterer, A. K. Elshennawy. (2005). Implementation of TQM and Lean Six Sigma Tools in Local Government: a Framework and a Case Study. Total Quality Management, $1179-1191$.

Sikander, T. (2015). A Theoretical Framework of Local Government. International Journal of Humanities and Social Science, 171-176.

Suárez-Barraza, M. F. (2013). Process Innovation in Local Governments: an empirical study of its continuous improvement efforts. Review of Business Management, 204-220.

Sunder, V. (2013). Synergies of Lean Six Sigma. The IUP Journal of Operations Management, 21-31.

Sunil Sharma, Anuradha R. Chetiya. (2012). An analysis of critical success factors for Six Sigma implementation. Asian Journal on Quality, 294 - 308.

Taylor et. al. (2014). Proposed Progression of Lean Six Sigma. The Journal of Technology Studies, 2-9.

X. Zhu, M. Hassan. (2012). Lean Six Sigma: A Literature Review. Interdisciplinary Journal of Conteporary Research In Business, 599605. 